\title{
Pozyskać Królestwo Polskie. Z dokumentacji Sekretariatu Generalnego Naczelnego Komitetu Narodowego z 1914 r. i pierwszej połowy 1915 r.
}

\begin{abstract}
Abstrakt: W artykule wykorzystano dokumentację z Archiwum Narodowego w Krakowie z zespołu Naczelnego Komitetu Narodowego. Materiały przedstawiają wiele szczegółowych analiz dotyczących Królestwa Polskiego, jego potencjału gospodarczego, nastrojów społeczeństwa, pozycji i kondycji partii i ugrupowań politycznych tam działających. Przyświecał temu główny cel - pozyskanie Królestwa Polskiego i wciagnięcie go w orbitę działań krakowskiego ośrodka. Dokumentacja ta pokazuje działania i problemy krakowskiego ośrodka na drodze do pozyskania partii i organizacji politycznych Królestwa, a przede wszystkim przekonania społeczeństwa do idei Legionów i opcji austro-polskiej.
\end{abstract}

Słow a kluczowe: Naczelny Komitet Narodowy, sekretariat Generalny NKN, opcja austro-polska, werbunek do Legionów w Królestwie Polskim, Królestwo Polskie w latach 1914-1915.

Abstract: The article is based on the archival material preserved in the National Archives in Krakow, in the fonds of the Supreme National Committee. The documents include many thorough analyses of the Polish Kingdom, its economic potential, the mood of the society, the position and condition of political parties and groups operating in its territories. This was made for one purpose: to win the people of the Polish Kingdom and drag them into the sphere of influence of the Krakow centre. The material reveals the activities and problems of Krakow centre on its way to win the Kingdom's political parties and organisations, and, above all, to win the sympathy of people for the idea of the Legions and Austro-Polish option.

Key w or d s: Supreme National Committee, General Secretariat of SNC, Austro-Polish option, recruitment to Legions in Kingdom of Poland, Kingdom of Poland in 1914-15. 
„Naród polski w osobie nas samych zdaje w obecnej chwili sprawę nie tylko wobec Historii, ale wobec współczesnej gry możnych wpływów za nami i przeciwko nam, z tego, czy jest zdolny sam być rządem i prawem”1.

Naczelny Komitet Narodowy (NKN) powstał w Krakowie 16 VIII 1914 r. Na jego czele staną prezes Koła Polskiego w Wiedniu i prezydent Krakowa Juliusz Leo, a potem prezes sekcji zachodniej NKN, prawnik i profesor Uniwersytetu Jagiellońskiego Władysław Leopold Jaworski. Akceptując orientację austro-polską i skupiając różne partie oraz stronnictwa w Galicji, pretendował on do roli ośrodka kierującego akcją niepodległościową. NKN stał się „najwyższą instancją” w dziedzinie organizacji polskich sił zbrojnych. Wkrótce też wydano uchwałę o tworzeniu Legionów Polskich ${ }^{2}$. NKN przez pierwsze miesiące rzeczywiście skupiał najważniejsze siły polityczne działające na ziemiach polskich. W październiku 1914 r. jednak narodowi demokraci i konserwatyści wschodniogalicyjscy opuścili jego szeregi ${ }^{3}$.

NKN powstał po nieudanej akcji wywołania powstania w Królestwie Polskim na początku sierpnia 1914 r. przez I kompanię kadrową i fiasku planów związanych z Rządem Narodowym. Obojętna w większości postawa społeczeństwa Królestwa na hasła powstańcze wywołała wprawdzie rozgoryczenie wśród polskich działaczy niepodległościowych, ale opanowanie Królestwa podległego Rosji stanowiło jeden z kluczowych elementów orientacji na państwa centralne. Czynnikiem wzmacniającym taką postawę było także pewne zaniepokojenie wywołane odezwą podpisaną przez wielkiego księcia Mikołaja 14 VIII 1914 r., w której to Rosja wzywała Polaków ze wszystkich zaborów do połączenia się pod „berłem cesarza rosyjskiego"4. NKN od początku swego istnienia gromadził informacje na temat Rosji, jej polityki wobec Królestwa, przyglądał się polskim ugrupowaniom i organizacjom działającym na terenie Rosji ${ }^{5}$.

Sekretariat Generalny NKN opracowywał wiele szczegółowych analiz dotyczących Królestwa Polskiego, jego potencjału gospodarczego, nastrojów

\footnotetext{
${ }^{1}$ Archiwum Narodowe w Krakowie, Zbiory online. NKN (dalej: ANK, NKN), 29/530/0/1.1/10, Sprawozdania ogólne Sekretariatu Generalnego z lat 1914-1916, Cyrkularz Sekretariatu Generalnego Naczelnego Komitetu Narodowego do Delegatów Prasowych za granica, k. 40.

${ }^{2}$ Szerzej zob. W. Suleja, Orientacja austro-polska w latach I wojny światowej (do aktu 5 listopada 1916 r.), Wrocław 1992; J. Pajewski, Odbudowa państwa polskiego 1914-1918, Warszawa 1985, s. 75-82; J. Sibora, Dyplomacja polska $w$ I wojnie światowej, Warszawa 2013, s. 16-24; M. Drozdowski, Dylematy polityki Naczelnego Komitetu Narodowego wobec Niemiec (do Aktu 5 listopada 1916 r.), „Studia Historyczne” 2012, z. 1 (217), s. 27-49; K. Srokowski, NKN. Zarys historii Naczelnego Komitetu Narodowego, Kraków 1923.

${ }^{3}$ Szerzej zob. J. Molenda, Pitsudczycy a narodowi demokraci 1908-1918, Warszawa 1980, s. $188-189$.

${ }^{4}$ Ibidem, s. 55.

${ }^{5}$ Dokumentacja na ten temat w: ANK, NKN, 29/530/0/1.1/44, Sekretariat Generalny. Rosja a Polska - omówienia ogólne. Ugrupowania polityczne i organizacje polskie w Rosji 1914-1918; 29/530/0/1.1/43, Rosja. Stosunki wewnętrzne i zewnętrzne.
} 
społeczeństwa, pozycji i kondycji partii oraz ugrupowań politycznych tam działających. Przyświecał temu główny cel - pozyskanie Królestwa Polskiego i wciagnięcie go w orbitę działań krakowskiego ośrodka. Na jesieni 1914 r. sekretarzem generalnym został Michał Sokolnicki, współpracownik komendanta Józefa Piłsudskiego. To Królestwo „miało być atutem, którym Piłsudski chciał się posługiwać w przetargach politycznych z władzami mocarstw centralnych i NKN”6. Tendencje do wzmocnienia działań związanych z Królestwem nasiliły się po zajęciu przez Austrię części terenów Królestwa. Dlatego 22 XI 1914 r. NKN przystapił do realizacji zadań określanych formuła „okres przejściowy w Królestwie”, czyli czas do planowanego zajęcia Warszawy przez wojska państw centralnych ${ }^{7}$. Stąd intensyfikacja działań, a także analiz sytuacji w Królestwie. 7 XII 1914 r. Jaworski przedłożył w Wiedniu memoriał w sprawie delegacji NKN w Królestwie. Pisał w nim: „Zadanie, które się otwiera w Królestwie Polskim przed NKN, polega na popieraniu świadomości społecznej, na rozszerzaniu zasadniczej idei NKN t. j. związku Polski z Austrią. Nie będzie łatwą rzeczą wypełnić to zadanie, aczkolwiek grunt jest dobrze przysposobiony [...]. Po zajęciu Królestwa będzie je musiała Austria zdobyć moralnie. Droga jednak do tego moralnego podboju wiedzie przez NKN"8. W memoriale tym Jaworski starał się przekonywać władze austriackie, że tylko z Austrią Polacy chca wchodzić w związki. Za niemożliwe z polskiego punktu widzenia uważał związki z Prusami i Rosja. Wprawdzie ze strony władz austriackich wiele było niekonsekwencji i braku zrozumienia dla spraw polskich, ale - jak wiadomo - 26 XII 1914 r. Naczelna Komenda Armii zezwoliła na werbunek do Legionów na terenach Królestwa zajętych przez państwa centralne. Natomiast w styczniu 1915 r. Departament Wojskowy NKN został przeniesiony na teren Królestwa, intensyfikacji uległa akcja werbunkowa ${ }^{9}$. NKN wysłał też do Królestwa swoich delegatów, którzy podjęli się m.in. akcji zakupu i rozdawnictwa żywności dla ludności, starali się aktywizować społeczeństwo do wspierania opcji polsko-austriackiej ${ }^{10}$. Już w grudniu Sokolnicki w raporcie do Jaworskiego sygnalizował, że trzeba położyć większy nacisk na przekonywanie strony austriackiej do wyjednania pozwoleń dla kurierów i wysłanników NKN do Królestwa ${ }^{11}$. W kolejnych

${ }^{6}$ Cyt. za: J. Holzer, J. Molenda, Polska w pierwszej wojnie światowej, Warszawa 1963, s. 87-88.

7 Za: J. Sibora, op. cit., s. 25.

${ }^{8}$ Dokumenty Naczelnego Komitetu Narodowego 1914-1917, Kraków 1917, dok. 38: W sprawie delegacji N.K.N. w Królestwie, s. 62.

9 Szerzej zob. M. Przeniosło, Placówki werbunkowe Departamentu Wojskowego Naczelnego Komitetu Narodowego na terenie okupacji austro-węgierskiej, „Res Historica” 2014, nr 37, s. $65-80$.

${ }^{10}$ Dokumenty Naczelnego Komitetu Narodowego..., dok. 56: Status delegacji NKN w Królestwie, s. 86; J. Holzer, J. Molenda, op. cit., s. 85-86.

11 ANK, NKN, 29/530/0/1.1/11, Sekretariat Generalny. Raporty sytuacyjne i prasowe Sekretarza Generalnego dla Prezesa NKN. Raport z 9 XII 1914 r., k. 2. 
raportach Sokolnicki przedkładał wnioski dotyczące organizacji NKN w Królestwie ${ }^{12}$. Przedstawił listę osób, które planował wysłać na teren Królestwa w celu prowadzenia akcji zapomogowej. Wśród proponowanych osób wymieniał m.in. Jędrzeja Moraczewskiego oraz swego brata Gabriela Sokolnickiego ${ }^{13}$. Z kolei Leon Wasilewski opracował „podręcznik administracyjny Królestwa” ${ }^{14}$.

Sekretariat Generalny NKN otrzymywał systematycznie raporty od Departamentu Wojskowego zaraz po jego przeniesieniu na teren Królestwa. Na początku było w nich dużo optymizmu co do szans pozyskania Królewiaków. W jednym z takich raportów z początku lutego 1915 r. czytamy:

Ludność Zagłębia Dąbrowskiego - na które głównie promieniuje D[epartament] W[ojskowy] przestała już wierzyć w powrót Moskali i w obietnice Mikołaja Mikołajewicza, zwłaszcza, - gdy usłyszała o okrucieństwach i gwałtach, których się dopuszczali Rosjanie wobec ludności polskiej w czasie ostatniej ofensywy na Królestwo. Bezładny odwrót ich, widok wynędzniałych, źle odzianych i uzbrojonych żołnierzy rosyjskich - podkopał na zawsze i rozwiał urok niezwyciężonej, olbrzymiej armii rosyjskiej w oczach społeczeństwa ${ }^{15}$.

Przekaz ten należy traktować z dużą ostrożnościa, jest niewątpliwie zbyt optymistyczny. Dotyczy tė̇ tylko Zagłębia Dąbrowskiego zdobytego przez wojska centralne. Wiemy jednak, że poczynania Niemców w tym rejonie były skandaliczne. Zatapiając fabryki i konfiskując surowce, nie mogli liczyć na życzliwość miejscowej ludności ${ }^{16}$. Marek Przeniosło dowodzi, jak trudna pracę na terenie Królestwa prowadzili emisariusze i oficerowie werbunkowi Departamentu Wojskowego NKN i z jakim oporem spotykali się w akcji prolegionowej ${ }^{17}$.

Bardzo wiele informacji na temat sytuacji w Królestwie Polskim, prób pozyskania go do działań NKN znajduje się w Archiwum Państwowym w Krakowie w zespole Archiwum Naczelnego Komitetu Narodowego. Ten ogromny zbiór jest od dziesięcioleci penetrowany przez badaczy. Dokumentacja ta obejmuje cały okres wojny i dotyczy różnorodnych kwestii. Na potrzeby tego artykułu wybrano tylko nieliczne dokumenty dotyczące Królestwa Polskiego z okresu od 1914 do lata 1915 r., czyli wycofania się Rosjan z Królestwa po klęskach militarnych i opanowania tych terenów przez wojska państw centralnych. Analizy sporządzane przez delegatów NKN do Królestwa często nie zawierają dat ani imiennych podpisów, jednak ich treść pozwala na wskazanie przybliżonego okresu powstania dokumentu.

\footnotetext{
${ }^{12}$ Ibidem, Raport z 22 XII 1914 r., k. 5-6.

${ }^{13}$ Ibidem, Raport z 4 I 1915 r., k. 10-11.

${ }^{14}$ Ibidem, Raport z 3 II 1915 r., k. 14-15.

15 Ibidem, 29/530/0/1.1/101, Sekretariat Generalny. Stosunki polityczne w Królestwie Polskim - materiały i omówienia ogólne 1914-1918. Sławków 6 II 1915 r., podpis K. D., k. 104.

16 Szerzej zob. J. Holzer, J. Molenda, op. cit., s. 110-111.

${ }_{17}$ M. Przeniosło, op. cit.
} 


\section{Stosunki gospodarcze w Królestwie Polskim}

W analizach sytuacji gospodarczej wskazywano na ogromne zniszczenie terenów Królestwa spowodowane działaniami wojennymi. Przemarsze wojsk i walki doprowadziły również do pauperyzacji społeczeństwa. W drugiej połowie 1914 r. dotyczyło to głównie zachodnich terenów Królestwa, czyli guberni kieleckiej, zachodnio-południowej części guberni radomskiej i środkowej części guberni warszawskiej. Pisano, iż „istnieją całe przestrzenie, gdzie nie pozostała prawie ani jedna wioska, wszystkie bowiem zostały popalone bądź to przez jedną bądź to przez druga stronę wojująca”. Podano, że w powiecie iłżeckim spalono 508 domów. Panuje tam nędza, wybuchają epidemie tyfusu i ospy ${ }^{18}$. Sytuacja ta stymulowała przemieszczanie się ludności do miast i wzrost liczby bezdomnych i bezrobotnych. W analizie powoływano się na doniesienia prasowe informujące o przybyciu do Warszawy uciekinierów żydowskich. Skrytykowano działania władz niemieckich na zajętych przez nich terenach Królestwa (tereny na północ i zachód od Będzina, linii kolejowej warszawsko-wiedeńskiej, Piotrkowa, Tomaszowa i Inowłodza). Pisano, że „gospodarka niemiecka na ziemiach Królestwa jest nadzwyczaj brutalna i surowa”, rekwizycje, kary za niewykonywanie zarządzeń władz, profanowanie kościołów i obrażanie uczuć religijnych stały się codziennością ${ }^{19}$. Dodajmy, że na początku wojny Jaworski w memoriale NKN skierowanym do ministra spraw zagranicznych Prus zwracał uwagę na dotkliwe represje, jakie stosują Niemcy na terenie Kalisza i Częstochowy. Sygnalizował, że taka postawa wpłynie niekorzystnie na stosunek ludności do państw centralnych i wywoła także negatywne skutki w przypadku wkroczenia wojsk niemieckich do Warszawy ${ }^{20} .29$ XII 1914 r. Jaworski złożył też memoriał w sprawie sytuacji gospodarczej w Królestwie. Pisał w nim, że tylko poprawa warunków egzystencji, a szczególnie dostarczenie ludności środków żywności może zmienić negatywne nastawienie społeczeństwa Królestwa do władz i armii niemiecko-austriackiej. Poprawa sytuacji gospodarczej ułatwiłaby bowiem NKN próby pozyskania ludności w celu wsparcia dla Legionów i „przychylnego usposobienia dla dążności Naczelnego Komitetu Narodowego"21.

Trochę lepiej wyglądała sytuacja na terenach zajętych przez wojska austriackie, aczkolwiek w wielu przypadkach działania tych władz określano jako „bezmyślne”. Uważano, że austriackie organy wykonawcze po prostu źle funkcjonują i stąd bałagan i brak logiki w ich działaniu. Skrytykowano

\footnotetext{
18 ANK, NKN, 29/530/0/1.1/10, Sprawozdania ogólne Sekretariatu Generalnego z lat 1914-1916, Stosunki gospodarcze w Królestwie Polskim, k. 2.

${ }^{19}$ Ibidem, k. 5.

${ }^{20}$ Dokumenty Naczelnego Komitetu Narodowego..., dok. 25: Z memoriału Naczelnego Komitetu Narodowego do ministra spraw zagranicznych w sprawie wydarzeń w Kaliszu i ewentualnego zajęcia Warszawy, s. 36-38.

${ }^{21}$ Ibidem, dok. 47: W sprawie położenia gospodarczego w Królestwie Polskim, s. 66-77.
} 
niezrozumiały zakaz przewozu żywności z powiatu do powiatu, nakładanie wysokich cen na żywność. Austriacką intendenturę określano jako „bezdennie głupią" albo obdzierajacca „niemiłosiernie ludność”22. Prawdopodobnie na podstawie tej analizy, przeprowadzonej przez wysłanników NKN na tereny Królestwa zajęte przez armię austriacka, wysłano 10 III 1915 r. do władz w Wiedniu pismo na temat stanu gospodarczego Królestwa. Pisano w nim m.in.:

Przez sparaliżowanie i zastój w rzemiośle, handlu i komunikacji zatrważajace rozmiary przybrał brak pracy i związana z nim nędza. Jeżeli nawet nie można oczekiwać pełnego reaktywowania przemysłu z powodu braku surowców, to można brakowi pracy przeciwdziałać przez podjęcie koniecznych robót publicznych i przez otwarcie zamkniętych kopalń, których produkcja znów mogłaby oddziałać żywo na przemysł ${ }^{23}$.

W analizach Sekretariatu Generalnego wiele miejsca poświęcono działalności w Królestwie Centralnego Komitetu Obywatelskiego (CKO) jako instytucji, „która postawiła sobie za zadanie bronić kraju wedle możności od ostatecznego upadku życia ekonomicznego" ${ }^{24}$. Komitet został utworzony na początku sierpnia 1914 r. i na jego czele stanął ziemianin i polityk, książę Zdzisław Lubomirski. Podlegały mu komitety na prowincji. CKO prowadził różnorodną działalność mającą na celu wspomaganie ludności na polu gospodarczym, humanitarnym, prawnym ${ }^{25}$. I to właśnie w oddolnych polskich inicjatywach analitycy NKN widzieli szansę na ratowanie zapaści gospodarczej Królestwa. Krytykując działania władz niemieckich i austriackich, uważano jednak, że to Rosja, najlepiej znająca te tereny i społeczeństwo, „największa daje Królestwu pomoc finansową" ${ }^{26}$. Ten paradoks miał rzeczywiście swoje uzasadnienie w faktach. CKO otrzymał przecież zezwolenie od władz rosyjskich na działalność oraz wprowadził wiele ulg podatkowych i pożyczkowych dla mieszkańców Królestwa, jak chociażby zawieszenie podatków do końca wojny, ceny ulgowe na różne towary.

22 ANK, NKN, 29/530/0/1.1/10, Sprawozdania ogólne Sekretariatu Generalnego z lat 19141916, k. 6.

${ }^{23}$ Dokumenty Naczelnego Komitetu Narodowego..., dok. 67: W sprawie stanu gospodarczego Królestwa, s. 100-101.

${ }^{24}$ ANK, NKN, 29/530/0/1.1/10, Sprawozdania ogólne Sekretariatu Generalnego z lat 19141916, k. 3-5.

${ }^{25}$ Szerzej zob. J. Pajewski, op. cit., s. 66; K. Dunin-Wąsowicz, Warszawa 1914-1918, Warszawa 1989, s. 11, 32; M. Gmurczyk-Wrońska, Adwokaci warszawscy w latach Wielkiej Wojny, w: Perspektywy przegranych i zwycięzców Wielkiej Wojny: zbiorowe tożsamości i indywidualne doświadczenia w Europie Środkowo-Wschodniej (1914-1921), seria: „Metamorfozy społeczne", t. XIX, Warszawa 2018, s. 343-346.

${ }^{26}$ ANK, NKN, 29/530/0/1.1/10, Sprawozdania ogólne Sekretariatu Generalnego z lat 1914-1916, Stosunki gospodarcze w Królestwie Polskim, k. 7. 


\section{Stronnictwa polityczne w Królestwie Polskim i kondycja społeczeństwa}

Ciekawym dokumentem, sporządzonym prawdopodobnie w marcu 1915 r. przez delegatów NKN w Królestwie, jest analiza sytuacji politycznej i społecznej na tych terenach ${ }^{27}$. Wprawdzie większość tekstu to omówienie partii i organizacji działajacych w Królestwa, ale dominuje myśl pozyskania Królestwa, szczególnie przekonania społeczeństwa do idei Legionów. Dokument wskazuje wręcz na niewiarygodne rozdrobnienie polityczne na terenie Królestwa. Kwestie te zostały wprawdzie przedstawione w literaturze ${ }^{28}$, ale dokładna analiza tego siedmiostronicowego dokumentu uszczegóławia naszą wiedzę.

Autorzy analizy przyznaja, że wybuch wojny nie wpłyną na zmianę liczby partii i stronnictw. Zaszła natomiast przemiana „w dynamice partyjnych poczynań”, partie zareagowały niezwykle żywo na wydarzenia wojenne ${ }^{29}$. Wyróżniono trzy obozy polityczne: obóz czynnie i biernie sprzyjający Rosji, centrum i obóz niepodległościowy. Obóz związany z Rosją to oczywiście Narodowa Demokracja i Stronnictwo Polityki Realnej. Widziano ich jako dwa bardzo zbieżne programowo ugrupowania. Nie dostrzegano różnic i wzajemnych krytyk oraz animozji, np. pomiędzy Romanem Dmowskim i Erazmem Piltzem $^{30}$. Pisano, że „Obie partie sa przeciwne wszelkim wystapieniom niezgodnym $\mathrm{z}$ interesem państwowości rosyjskiej i zwalczaja usiłowania wytworzenia polskiej siły politycznej" ${ }^{31}$. W analizie tej znalazły się bardzo krytyczne opinie i oceny obydwu ugrupowań, ich działalności przeciwko NKN i Legionom ${ }^{32}$. Pisano, iż partie te przedstawiaja akcję werbunkową do Legionów jako „wynik działania ajentów pruskich, prowokatorów dążących do skompromitowania polskiego społeczeństwa przed rządem rosyjskim,

${ }^{27}$ Ibidem, Sprawozdania ogólne Sekretariatu Generalnego z lat 1914-1916, Sprawozdanie Sekretariatu Generalnego Naczelnego Komitetu Narodowego. Królestwo Polskie: Stronnictwa polityczne, k. 8-14; Wnioski delegatów Naczelnego Komitetu Narodowego działajacych na terenie Królestwa Polskiego wniesione na plenarne posiedzenie NKN w dniu 3-5 kwietnia 1915, w: Dokumenty Naczelnego Komitetu Narodowego..., dok. 73, s. 115-119. Dokument publikowany w Dokumenty Naczelnego Komitetu Narodowego 1914-1917 jest bardzo skrótowy, w części tylko oddaje treść dokumentu archiwalnego, niemniej jednak z uwagi na brak daty w dokumencie archiwalnym prawdopodobnie chodzi o ten czas i tych delegatów NKN wysłanych na teren Królestwa.

28 J. Holzer, J. Molenda, op. cit.; J. Molenda, op. cit.

${ }^{29}$ ANK, NKN, 29/530/0/1.1/10, Sprawozdania ogólne Sekretariatu Generalnego z lat 1914-1916, Sprawozdanie Sekretariatu Generalnego Naczelnego Komitetu Narodowego. Królestwo Polskie: Stronnictwa polityczne, k. 8.

${ }^{30}$ Pisze o tym szerzej A. Szczepaniak, Od autonomii do niepodlegtości. Działalność polityczna Erazma Piltza w latach 1914-1929, Opole 2015, s. 74 i n.

31 ANK, NKN, 29/530/0/1.1/10, Sprawozdania ogólne Sekretariatu Generalnego z lat 1914-1916, Sprawozdanie Sekretariatu Generalnego Naczelnego Komitetu Narodowego. Królestwo Polskie: Stronnictwa polityczne, k. 9.

32 Szerzej zob. J. Holzer, J. Molenda, op. cit., s. 120-126; J. Molenda, op. cit., s. 204-206. 
aby tenże nie urzeczywistnił odezwy Wielkiego Księcia" ${ }^{33}$. Wprawdzie wskazywano Dmowskiego i Zygmunta Balickiego jako kierowników endecji, ale stwierdzano, iż „tajną sprężyną poruszającą całą organizacją jest jednak sui generis massonerya, zakonspirowana, z niewielkiej liczby osób złożona Liga Narodowa" ${ }^{34}$. To problem niewątpliwie złożony i do dzisiaj, pomimo licznych publikacji i sporów, nierozstrzygnięty. Niemniej jednak delegaci NKN dokonując analizy działalności endecji, patrzyli na to ugrupowanie poprzez ich publicystykę głównie w „Gazecie Warszawskiej”. W świetle obecnej pokaźnej literatury, wiemy, jak złożonym problemem, szczególnie dla Dmowskiego, była Rosja. Prowadził on z nią nieustanna grę, więc wywody zawarte $\mathrm{w}$ analizach NKN stanowią niewatpliwie wielkie uproszczenie. Dmowski opierając się na państwach ententy, do których też należała Rosja, próbował doprowadzić do umiędzynarodowienia sprawy polskiej. Umożliwiłoby to „wydarcie” spraw polskich z rąk Rosji. O tym nie pisano w analizowanym dokumencie, aczkolwiek Dmowski rozwijał rzeczywiście wielka aktywność międzynarodowa dopiero od końca 1915 r. ${ }^{35}$ Podkreślić jednak należy, że delegaci dostrzegali początki jego międzynarodowej działalności i pisali o kontaktach w Londynie, Paryżu, Wiedniu i Rzymie ${ }^{36}$.

Do obozu biernie popierającego Rosję analitycy NKN zaliczali: była frakcję Polskiej Partii Socjalistycznej, czyli PPS-Lewicę, Socjaldemokrację Królestwa Polskiego i Litwy ${ }^{37}$ oraz chrześcijańską demokrację. Pisano jednak:

Wszystkie te partie w części zajętej przez Rosję żadnego wpływu politycznego nie posiadają. Konkurują wzajemnie i walczą na tle uzyskania wyłącznej reprezentacji klasy robotniczej w zrzeszeniach ekonomicznych i instytucjach filantropijno-kulturalnych. Wyraźnie nie opowiadając się za Rosją wysuwają naprzód hasło obojętności i indolencji, głoszone pod pozorem partyjnego zwalczania wojny, jako zapasów toczonych przez burżuazję i nie obchodzących neutralnego proletariatu. Bliższy jeszcze związek z N.D. to fakt bardzo prawdopodobny z którym należy się liczyćc ${ }^{38}$.

${ }_{33}$ ANK, NKN, 29/530/0/1.1/10, Sprawozdania ogólne Sekretariatu Generalnego z lat 1914-1916, Sprawozdanie Sekretariatu Generalnego Naczelnego Komitetu Narodowego. Królestwo Polskie: Stronnictwa polityczne, k. 9.

${ }^{34}$ Ibidem, k. 9.

${ }^{35}$ R. Wapiński, Roman Dmowski, Lublin 1989, s. 212 i n.; T. Schramm, Dyplomacja francuska wobec kwestii autonomii Polski w 1916 r., w: Ku Niepodlegtej. Ścieżki polskie i francuskie 1795-1918, red. M. Willaume, Lublin 2005, s. 501-513; M. Gmurczyk-Wrońska, Czy rok 1916 byt istotny dla spraw polskich w polityce Francji?, „Dzieje Najnowsze” 2016, nr 3, s. 37-50.

36 ANK, NKN, 29/530/0/1.1/10, Sprawozdania ogólne Sekretariatu Generalnego z lat 1914-1916, Sprawozdanie Sekretariatu Generalnego Naczelnego Komitetu Narodowego. Królestwo Polskie: Stronnictwa polityczne, k. 9.

${ }^{37}$ Obydwie partie po wybuchu wojny współpracowały w ramach Międzynarodowej Rady Robotniczej i Robotniczego Komitetu Gospodarczego. Szerzej zob. J. Holzer, J. Molenda, op. cit., s. 103-106, 344 .

38 ANK, NKN, 29/530/0/1.1/10, Sprawozdania ogólne Sekretariatu Generalnego z lat 1914-1916, Sprawozdanie Sekretariatu Generalnego Naczelnego Komitetu Narodowego. Królestwo Polskie: Stronnictwa polityczne, k. 10. 
Ciekawą analizą była próba przedstawienia centrum politycznego. Do grupy „stojących w opozycji do radykalnego moskalofilstwa” ${ }^{39}$ zaliczono Frondę Realistów Narodowej Demokracji, czyli neorealistów, secesję oraz postępowców. Secesję określono jako „skupienie młodego pokolenia N.D., zwalczające otwarcie Dmowskiego i jego satelitów, a odnoszące się do Legionów z sympatia. Cały kierunek stoi intelektualnie bardzo wysoko i należy wielu ludzi nauki, w ogóle czynniki nie znoszące metody i dyktatury Dmowskiego"40. Z grupy tej podano nazwisko Stanisława Bukowieckiego, którego określono jej „moralna głowa” ${ }^{41}$. Należy podkreślić, że Bukowiecki był rzeczywiście postacia wyjątkowa. Adwokat, do 1909 r. związany z endecja, współzałożyciel Związku Młodzieży Polskiej „Zet”, studiował na uniwersytetach w Warszawie i Heidelbergu, gdzie zdobył tytuł doktora praw. W młodości angażował się w obronę górników, zabiegał o unormowanie prawa górniczego ${ }^{42}$. Po utworzeniu Tymczasowej Rady Stanu Bukowiecki staną na czele Departamentu Sprawiedliwości. Wykazywał się niezwykłą determinacją w rozmowach z władzami niemieckimi dotyczącymi tworzenia polskiego sądownictwa ${ }^{43}$.

Analitycy NKN dość pozytywnie pisali też o niektórych członkach Polskiej Partii Postępowej, szczególnie o adwokacie Stanisławie Patku, redaktorze tygodnika „Widnokrag” Wincentym Rzymowskim i działaczce społecznej Stefanii Sempołowskiej. Chociaż zarzucano im obecnie „nijakość” i liczenie na „pomoc postępowców rosyjskich”44. W pewnym stopniu tak było. Patek wprawdzie od 1905 r. utrzymywał kontakty z Piłsudskim, ale sympatyzował też z liberałami rosyjskimi. Był on przede wszystkim znanym adwokatem, obrońca więźniów politycznych. Wspomagała go w tych pracach często Sempołowska. Patek posiadał liczne kontakty międzynarodowe dzięki powiązaniom wolnomularskim i związkom z liberałami. Grupy te wzajemnie przenikały się i tworzyły specyficzne mikrośrodowiska. Działały tu powiązania nie tylko towarzyskie, ale także ideowe. Patek pracował w środowiskach, które próbowały przenieść na grunt polski wiele zachodnioeuropejskich wzorców i doświadczeń z zakresu prawa, handlu oraz kwestii ustrojowych. Po usunięciu przez władze rosyjskie z adwokatury w $1911 \mathrm{r}$. rozpoczął pracę na stanowisku prezesa Rady Towarzystwa Wzajemnego Kredytu w Warszawie, jednego z licznych działających wówczas towarzystw kredytowych. W 1916 r. brał udział w organizowaniu municypalności Warszawy, został członkiem

39 Ibidem.

${ }^{40}$ Ibidem.

${ }^{41}$ Ibidem.

${ }^{42}$ Z. Nagórski, Ludzie mego czasu, Paryż 1964, s. 37-45 (biogram Bukowieckiego).

${ }^{43}$ M. Gmurczyk-Wrońska, Adwokaci warszawscy..., s. 331-382; W. Suleja, Tymczasowa Rada Stanu, Warszawa 1998, s. 183-184.

${ }^{44}$ ANK, NKN, 29/530/0/1.1/10, Sprawozdania ogólne Sekretariatu Generalnego z lat 1914-1916, Sprawozdanie Sekretariatu Generalnego Naczelnego Komitetu Narodowego. Królestwo Polskie: Stronnictwa polityczne, k. 10. 
pierwszej Rady Miejskiej i wiceprezesem jej Komisji Prawniczej. W 1916 r. wszedł do Rady Narodowej, a w 1917 r. włączył się w organizowanie sądownictwa i został przewodniczącym Departamentu Karnego Sądu Apelacyjnego, w 1918 r. zaś członkiem Sądu Najwyższego ${ }^{45}$.

Sporo miejsca w analizowanym dokumencie poświęcono obozowi niepodległościowemu, czyli siłom politycznym wchodzącym w skład Komisji Tymczasowej Skonfederowanych Stronnictw Niepodległościowych i Zjednoczonych Organizacji Niepodległościowych. Kwestie te zostały już dokładnie przedstawione w literaturze. Analitycy NKN pisali dość krytycznie o niektórych ugrupowaniach zachowujących dystans i powściagliwość wobec akcji legionowych. Wymieniali Narodowy Związek Chłopski (NZCh), Narodowy Związek Robotniczy (NZR) i Związek Inteligencji Niepodległościowej. Wprawdzie potencjał widzieli w Związku Chłopskim, Związku Patriotów oraz Lewicy Socjalistycznej (PPS) wspierajacej Legiony, ale ugrupowania te zostały silnie osłabione wskutek aresztowań i wysyłki na Syberię głównych ich członków.

NKN wiązał duże nadzieje z Konfederacją Polską. Powstała ona w listopadzie 1914 r. po rozpadzie Zjednoczenia Organizacji Niepodległościowych. W jej skład wchodziły: NZR, NZCh, Związek Inteligencji Niepodległościowej i Związek Nauczycielstwa Polskiego ${ }^{46}$. Pisano:

Celem Konfederacji jest wyzyskanie wojny dla zdobycia niepodległości drogą walki zbrojnej. Zajmuje stanowisko ponadpartyjne, tworzy organizację cywilna, militarna, skarbową i dyplomatyczną i jest władzą tajna. Uznawszy naród polski za neutralny nie chce chwilowo przesądzać, przeciw któremu z wrogów walczyć będzie. N.K.N. zarzuca jawność i hasła jedności narodowej. Legalność w stosunku do zaborcy i użycie w ruchu żywiołów kontrrewolucyjnych stały się przyczyną fiaska politycznego i rozbicia. Uznaje jednak Legiony za zawiązek armii polskiej i zasługę N.K.N. stworzenia warunków dla aktywnych wystapień ${ }^{47}$.

Konfederacja działała do sierpnia 1915 r.

W ocenie analityków bardziej korzystne warunki do uzyskania wsparcia przez NKN były na terenach zdobytych przez Austrię. Przyznawano, że „partie sprzyjające Rosji muszą chodzić w masce, a partie niepodległościowe moga otwarcie propagować swe dążenia"48. Szczególnie dobrze sytuacja wyglądała w Sosnowcu i Piotrkowie, gdzie uwidoczniło się silne wsparcie dla Legionów, zwłaszcza okazywane przez NZCh. Wprawdzie jego aktywność była największa na terenach Lubelszczyzny, ale gdzie tylko może, „w proklamacjach i odezwach

\footnotetext{
${ }_{45}$ M. Gmurczyk-Wrońska, Stanistaw Patek. Raporty i korespondencja z Moskwy (1927-1932), wyd. 2, Warszawa 2013, s. 44-45.

${ }^{46}$ Szerzej zob. J. Holzer, J. Molenda, op. cit., s. 86, 331-332.

${ }^{47}$ ANK, NKN, 29/530/0/1.1/10, Sprawozdania ogólne Sekretariatu Generalnego z lat 1914-1916, Sprawozdanie Sekretariatu Generalnego Naczelnego Komitetu Narodowego. Królestwo Polskie: Stronnictwa polityczne, k. 11.

${ }^{48}$ Ibidem, k. 12.
} 
gorąco zachęca do Legionów" 49 . NKN mógł liczyć także na poparcie PPS, NZR, Zjednoczonej Młodzieży Polskiej i Ligi Kobiet w Łodzi. Partie te 16 I 1915 r. utworzyły Komitet Okręgowy Zjednoczenia Organizacji Niepodległościowych.

Wprawdzie już w pierwszej połowie 1915 r. NKN mógł liczyć na wsparcie wielu partii i organizacji politycznych działających na terenie Królestwa ${ }^{50}$, to jednak zdawano sobie sprawę z nikłego odziaływania tych partii na społeczeństwo. Przyznawano, iż partie te nie sa liczne i „nie przedstawiają bez reszty zbiorowej woli, która odgradza się od innych murem niechęci i lekceważenia”, „Królestwo w olbrzymiej przewadze nie należy do żadnej partii” ${ }^{2}$. Bezpartyjność popierała nawet inteligencja, która w części skupiona wokół takich pism, jak „Kurier Warszawski”, „Świat” i „Tygodnik Ilustrowany” sceptycznie oceniała partyjność. Analitycy NKN określali je nawet mianem „obozu bezpartyjnych” i podkreślali, że skupia on najdzielniejsze jednostki. Wśród nich wymieniano przykładowo filozofa, myśliciela politycznego Edwarda Abramowskiego, inżyniera i działacza spółdzielczego Zygmunta Chmielewskiego, także działacza spółdzielczego Stanisława Wojciechowskiego. To przecież w dużym stopniu obóz bezpartyjny tworzył CKO, dajac wyraz „wysokiego poczucia obywatelskiego i niemałej zdolności organizacyjnej”52. Konkludowano:

I tę masę bezpartyjnych mieszczącą się w nikłem i niezdecydowanem centrum, bo ogarniająca całe niemal społeczeństwo, musi się stoczyć walka między jedynymi istniejącemi skupieniami polskiej opinii - t. j. między N.D. a kierunkiem Legionów. Walka ta dla nas nie będzie łatwa. Owa większość narodu, obroną na wołanie do broni, nie chce nic stawić na kartę. Nie łudzi się, że zwycięska Rosja zechce stworzyć autonomiczny ustrój scalonym ziemiom Polski i widzi w niej groźnego wroga. A jednak pewna zwycięstwa Rosji, paraliżowana strachem przed Prusami i nowym rozdarciem Królestwa, kurczy swą działalność do akcji gospodarczej i cofa się przed jakiemkolwiek eksponowaniem swego bezpieczeństwa, przed każdą formą ryzyka ${ }^{53}$.

[Stanu tego] nie zdoła się zmienić lub znieść hasłem przeciwnem; nie podziałają na nia w szczególności żadne motywy natury uczuciowej. Przeciwstawić jej można tylko siłę faktów; fakt przegranej Rosji podziała z piorunująca potęgą na całość rozrosłej szeroko orientacji rosyjskiej; fakt pozostawienia Królestwa całością i możność przyłączenia go do Austrii zdarły nagle maskę wszystkich frazesów orientacji antyniemieckiej; faktyczna siła, sprawność organizacyjna Legionów skupiły wszystkie, rozpierzchłe jeszcze i nieustalone żywioły niepodległościowe przy ich sztandarze. Nade wszystko jednak chwila wzięcia Warszawy zdziała przełom w orientacji Królestwa ${ }^{54}$.

49 Ibidem, k. 13.

${ }^{50}$ Wynika to także z publikowanych deklaracji partii w Dokumentach Naczelnego Komitetu Narodowego...

${ }^{51}$ ANK, NKN, 29/530/0/1.1/10, Sprawozdania ogólne Sekretariatu Generalnego z lat 1914-1916, Sprawozdanie Sekretariatu Generalnego Naczelnego Komitetu Narodowego. Królestwo Polskie: Stronnictwa polityczne, k. 13.

52 Ibidem.

${ }^{53}$ Ibidem, k. 14.

${ }^{54}$ Ibidem. 
Rosjanie opuścili Warszawę 5 VIII 1915 r.

NKN z wielką determinacja prowadził obserwację i działania na terenie Królestwa Polskiego. Wychodząc z założenia, iż Królestwo „nie jest i nie było nigdy moskalofilskie [...] nie ulega natchnieniom i rządom narodowej demokracji” ${ }^{55}$, wierzono w przekonanie społeczeństwa do idei Legionów i koncepcji austro-polskiej. Po wycofaniu się Rosjan z Królestwa w lecie 1915 r. NKN stanął przed kolejnymi, jeszcze bardziej złożonymi problemami związanymi z funkcjonowaniem Królestwa pod okupacją państw centralnych.

\section{Streszczenie}

Powstały w sierpniu 1914 r. w Krakowie Naczelny Komitet Narodowy prezentując opcję austro-węgierska, dokładał wszelkich starań, aby włączyć do swych działań znajdujące się pod panowaniem rosyjskim Królestwo Polskie. W miarę zdobywania tych obszarów przez wojska państw centralnych mogło wydawać się, że sytuacja będzie sprzyjać planom krakowskiego ośrodka. Delegaci i emisariusze Sekretariatu Generalnego NKN przygotowali wiele ciekawych analiz sytuacji gospodarczo-politycznej w Królestwie, kondycji i stosunku społeczeństwa Królestwa do idei Legionów i opcji NKN. W artykule wykorzystano dokumentację z Archiwum Narodowego w Krakowie z zespołu Naczelny Komitet Narodowy.

W analizach sytuacji gospodarczej wskazywano na ogromne zniszczenie terenów Królestwa spowodowane działaniami wojennymi, przemarszami wojsk, rekwizycjami dokonywanymi przez wojsko. Krytykowano działania władz niemieckich, ale także i austriackich. Wprawdzie już w pierwszej połowie 1915 r. NKN mógł liczyć na wsparcie wielu partii i organizacji politycznych działających na terenie Królestwa, to jednak zdawano sobie sprawę z nikłego odziaływania tych partii na społeczeństwo. Przyznawano, iż partie te nie sa liczne i nie przedstawiają zbiorowej woli społeczeństwa. Większość bowiem mieszkańców Królestwa to ludzie bezpartyjni. Rekrutujacca się w dużym stopniu z tego obozu bezpartyjnych inteligencja była najbardziej pożądaną grupa. Krakowski ośrodek zdawał sobie sprawę, iż walka o Królestwo to także starcia z endecja, realistami i skrajną lewica. Niemniej jednak celem pozostawało społeczeństwo i dążność do przekonania go do opcji NKN.

Analitycy NKN w pierwszych miesiącach 1915 r. widzieli, w jak ogromnym stopniu życie polityczne Królestwa zostało zduszone. Dominującym problemem stały się kwestie ekonomiczne. Po wycofaniu się Rosjan z Królestwa w lecie 1915 r. NKN staną przed kolejnymi, jeszcze bardziej złożonymi problemami związanymi z funkcjonowaniem Królestwa pod okupacją państw centralnych.

\section{To Win the Kingdom of Poland. From the Documents of the General Secretariat of the Supreme National Committee of 1914 of the First Half of 1915}

In August 1914 in Krakow, the Supreme National Committee was established presenting the Austro-Hungarian option; it made every effort to draw into the sphere of its activities the Kingdom of Poland under the Russian power. As the troops of the Central Powers conquered these lands, it could seem that the situation was favourable to the plans of the

${ }^{55}$ Ibidem, Sekretariat Generalny. Stosunki polityczne w Królestwie Polskim - materiały i omówienia ogólne 1914-1918, k. 26, bez daty i podpisu. 
Committee. Delegates and emissaries of the General Secretariat of the Committee performed many interesting analyses of the economic and political situation in the Polish Kingdom, the conditions and attitudes of the Kingdom's society towards the idea of Legions and the option supported by the Committee. The article is based on the archival material preserved in the National Archives in Krakow, in the fonds of the Supreme National Committee.

The analyses of the economic situation pointed out to the widespread destruction in the territories of the Polish Kingdom caused by the war operations, marches of the troops, and requisitions by the armies. They criticised actions of the German authorities, but also of the Austrian ones. Although already in the first half of 1915 the Committee could count on the support of many political parties and organisations operating in the territories of the Polish Kingdom, the authors of the analyses were aware of the little influence of those parties on the society. They admitted that these organisations were not numerous and that they did not represent the collective will of the society, as a majority of people living in the Kingdom of Poland did not belong to any organisation. The most desired group was the intelligentsia, recruiting in its large part from this camp of non-party people. The Krakow Committee was also aware of the fact that the fight for the Polish Kingdom meant the struggles with the supporters of the National Democratic Party, realists and radical left-wingers. Nevertheless, the goal was to win over the society for the option backed by the Supreme National Committee.

In the first months of 1915, the analysts of the Committee saw how much political life was in the Kingdom of Poland was suppressed. Economic questions became the dominant problem. After the Russian withdrew from the Polish Kingdom in the summer of 1915, the Committee faced other, even more complicated issues related to the functioning of the Kingdom under the occupation of the Central Powers.

\section{Bibliografia}

Drozdowski M., Dylematy polityki Naczelnego Komitetu Narodowego wobec Niemiec (do Aktu 5 listopada 1916 r.), „Studia Historyczne” 2012, z. 1 (217), s. 27-49.

Dunin-Wassowicz K., Warszawa 1914-1918, Warszawa 1989.

Gmurczyk-Wrońska M., Adwokaci warszawscy w latach Wielkiej Wojny, w: Perspektywy przegranych $i$ zwycięzców Wielkiej Wojny: zbiorowe tożsamości i indywidualne doświadczenia w Europie Środkowo-Wschodniej (1914-1921), seria: „Metamorfozy społeczne”, t. XIX, Warszawa 2018, s. 343-346.

Gmurczyk-Wrońska M., Czy rok 1916 byt istotny dla spraw polskich w polityce Francji?, „Dzieje Najnowsze” 2016, nr 3, s. 37-50.

Gmurczyk-Wrońska M., Stanistaw Patek. Raporty i korespondencja z Moskwy (1927-1932), wyd. 2, Warszawa 2013.

Holzer J., Molenda J., Polska w pierwszej wojnie światowej, Warszawa 1963.

Molenda J., Pitsudczycy a narodowi demokraci 1908-1918, Warszawa 1980.

Pajewski J., Odbudowa państwa polskiego 1914-1918, Warszawa 1985.

Przeniosło M., Placówki werbunkowe Departamentu Wojskowego Naczelnego Komitetu Narodowego na terenie okupacji austro-węierskiej, „Res Historica” 2014, nr 37, s. 65-80.

Schramm T., Dyplomacja francuska wobec kwestii autonomii Polski w 1916 r., w: Ku Niepodlegtej. Ścieżki polskie i francuskie 1795-1918, red. M. Willaume, Lublin 2005, s. 501-513.

Sibora J., Dyplomacja polska w I wojnie światowej, Warszawa 2013.

Srokowski K., NKN. Zarys historii Naczelnego Komitetu Narodowego, Kraków 1923.

Suleja W., Orientacja austro-polska w latach I wojny światowej (do aktu 5 listopada 1916 r.), Wrocław 1992.

Suleja W., Tymczasowa Rada Stanu, Warszawa 1998. 
Szczepaniak A., Od autonomii do niepodlegtości. Działalność polityczna Erazma Piltza w latach 1914-1929, Opole 2015.

Wapiński R., Roman Dmowski, Lublin 1989.

Małgorzata Gmurczyk-Wrońska - dr hab., prof. Instytutu Historii Polskiej Akademii Nauk, członek Pracowni Dziejów Dyplomacji i Systemów Totalitarnych. Główne pola badawcze to: historia dyplomacji, stosunki międzynarodowe, polska polityka zagraniczna w XX w., stosunki polsko-francuskie i polsko-rosyjsko/sowieckie w XX w. E-mail: mwronska5@wp.pl.

Małgorzata Gmurczyk-Wrońska - Dr hab., professor at the Tadeusz Manteuffel Institute of History of the Polish Academy of Sciences, member of the Department of History of Diplomacy and Totalitarian Systems. The main research fields cover: the history of diplomacy, international relations, Polish foreign policy in the 20th century, Polish-French and Polish-Russian/Soviet relations in the 20th century. E-mail: mwronska5@wp.pl. 